ISSN. 2775-4324 (Online)

Journal of Physical Activity and Sports

Volume 2, Nomor 3, Desember 2021, 404-409

Journal of Physical Activity and Sports

\title{
MOTIVASI PESERTA PELATIHAN INSTRUKTUR SENAM AEROBIK LEVEL 2 DI LKP GRIYA DINA KABUPATEN DEMAK JAWA TENGAH
}

\author{
Asiska Doni Oktafiyanto ${ }^{1}$, Donny Anhar Fahmi ${ }^{2}$ \\ Pendidikan Jasmani Kesehatan dan Rekreasi, Universitas PGRI Semarang \\ doktafiyanto@gmail.com
}

\begin{abstract}
This research was motivated by the researcher's anxiety about the motivation of the training participants of level 2 aerobics instructor training which was caused by the researcher's doubts about the motivation of the participants of the level 2 aerobic exercise instructor training at LKP Griya Dina, Demak Regency. The purpose of this study was to determine the intrinsic motivation and extrinsic motivation of the training participants of level 2 aerobics instructor at LKP Griya Dina, Demak Regency. The researcher used a descriptive qualitative approach. The research location is LKP Griya Dina, Demak Regency. The informants in this study were the Chairperson, Administrators, LKP Griya Dina instructor trainers, and training participants for level 2 aerobics instructors. Data collection techniques in this study used several techniques, namely observation, interviews, and documentation. The data validity technique in this research is data triangulation. The analysis was carried out using a descriptive analysis model. The purpose of this study was to determine the intrinsic motivation and extrinsic motivation of the training participants of level 2 aerobics instructor at LKP Griya Dina, Demak Regency. The results showed that the trainees had an internal drive or intrinsic motivation as well as an external drive or extrinsic motivation that encouraged participants to attend level 2 aerobic exercise instructor training at LKP Griya Dina, Demak Regency. Regarding the participants' interest in becoming an aerobics instructor in Demak Regency, the researchers received an answer from the results of interviews with training participants that the trainees were also interested in becoming an aerobics instructor in Demak Regency.
\end{abstract}

Kata kunci : Motivation, Gymnastics Instructor, Aerobic Gymnastics, LKP

\begin{abstract}
Abstrak
Penelitian ini dilatar belakangi oleh keresahan peneliti tentang motivasi peserta pelatihan instruktur senam aerobik level 2 yang disebabkan keraguan peneliti terhadap motivasi peserta pelatihan instruktur senam aerobik level 2 di LKP Griya Dina Kabupaten Demak. Tujuan penelitian ini untuk mengetahui motivasi intrinsik dan motivasi ekstrinsik peserta pelatihan instruktur senam aerobik level 2 di LKP Griya Dina Kabupaten Demak. Peneliti menggunakan pendekatan kualitatif deskriptif. Lokasi penelitian di LKP Griya Dina Kabupaten Demak. Informan dalam penelitian ini adalah Ketua, Pengurus, Pelatih instruktur LKP Griya Dina, dan Peserta Pelatihan instruktur senam aerobik level 2. Teknik pengumpulan data pada penelitian ini menggunakan bebrapa teknik, yaitu observasi, wawancara, dan dokumentasi. Teknik keabsahan data pada penelitian ini adalah triangulasi data.
\end{abstract}


Analisi yang dilakukan menggunakan model analisis deskriptif. Tujuan penelitian ini adalah untuk mengetahui motivasi intrinsik dan motivasi ekstrinsik peserta pelatihan instruktur senam aerobik level 2 di LKP Griya Dina Kabupaten Demak. Hasil penelitian menunjukkan bahwa peserta pelatihan memiliki dorongan dari dalam diri atau motivasi intrinsik dan juga dorongan dari luar diri atau motivasi ekstrinsik yang mendorong peserta untuk mengikuti pelatihan instruktur senam aerobik level 2 di LKP Griya Dina Kabupaten Demak. Terkait minat peserta untuk menjadi instruktur senam aerobik di Kabupaten Demak, peneliti mendapatkan jawaban dari hasil wawancara dengan peserta pelatihan bahwa peserta pelatihan juga berminat menjadi instruktur senam aerobik di Kabupaten Demak.

Kata kunci : Motivasi, Instruktur Senam, Senam Aerobik, LKP

\section{PENDAHULUAN}

Olahraga sangat penting bagi kehidupan manusia untuk mewujudkan manusia yang sehat jasmani dan rohani. Olahraga adalah segala kegiatan yang sistematis untuk mendorong, membina, serta mengembangkan potensi jasmani, rohani dan sosial (Undang-undang Republik Indonesia Nomor 3 Tahun 2005 Tentang Sistem Keolahragaan Nasional). Berdasarkan fungsi dan tujuan olahraga, kita mengenal berbagai bentuk kegiatan olahraga, seperti (1) Olahraga pendidikan yang bertujuan untuk memperoleh pengetahuan, kepribadian, keterampilan, kesehatan dan kebugaran jasmani (2) Olahraga rekreasi yang bertujuan untuk kesehatan, kebugaran jasmani dan kegembiraan (3) Olahraga amatir adalah olahraga yang dilakukan atas dasar kecintaan atau kegemaran berolahraga (4) Olahraga profesional yang bertujuan untuk memperoleh pendapatan dalam bentuk uang atau bentuk lain yang didasarkan atas kemahiran berolahraga (5) Olahraga penyandang cacat adalah olahraga yang khusus dilakukan sesuai dengan kondisi kelainan fisik dan/atau mental seseorang (Undang-Undang Republik Indonesia Nomor 3 Tahun 2005 Tentang Sistem Keolahragaan Nasional). Masyarakat bisa memilih olahraga apa yang ingin dilakukan sesuai dengan keinginan untuk menjaga kesehatan tubuh (Ircham Nur Majid, 4(2):2015).

Menurut undang-undang sistem pendidikan nasional nomor 20 tahun 2003 menyebutkan bahwa jalur pendidikan terdiri atas pendidikan formal, nonformal, dan informal yang saling melengkapi, jalur pendidikan sekolah melalui kegiatan belajar mengajar secara berjenjang dan berkesinambungan. Pendidikan dalam hal ini yang dimaksud pendidikan nonformal adalah pendidikan yang tidak terpaku pada kurikulum yang ada. Program pendidikan nonformal menyangkut empat macam kegiatan antara lain berupa pendidikan dasar serta kegiatan yang ada hubungannya dengan usaha peningkatan pengetahuan dan keterampilan (Rahmawati \& Mulyono, 2016:176). 
Lembaga Kursus dan Pelatihan (LKP) Griya Dina Kabupaten Demak merupakan salah satu lembaga pendidikan nonformal yang memiliki berbagai macam program untuk meningkatkan keterampilan warga belajar. LKP GRIYA DINA Demak juga memiliki sanggar senam yang di dalamnya terdapat berbagai macam kegiatan senam, diantaranya adalah senam aerobik, body leguage, dan zumba. Peneliti memilih pelatihan senam aerobik karena, LKP GRIYA DINA Demak mengadakan kursus dan pelatihan instruktur senam aerobik level 2 (dua) yang bekerjasama dengan Kementrian Pendidikan dan Kebudayaan Republik Indonesia. Menurut UU No. 3 Tahun 2005 pasal 10 Masyarakat berkewajiban memberikan dukungan sumber daya dalam penyelenggaraan keolahragaan.

Pelatihan yang diadakan oleh LKP Griya Dina bertujuan untuk menciptakan isntruktur senam aerobik yang Takwa Kepada Tuhan Yang Maha Esa, berkualitas, dan profesonal. LKP Griya Dina sudah beberapa kali mengadakan pelatihan senam aerobik. Pada pelatihan senam aerobik tahun 2020 diikuti oleh 20 peserta, hal tersebut disebabkan karena pelatihan dilakukan pada saat pandemi Covid-19 sehingga ada pembatasan peserta pelatihan. Pada saat pelatihan ditahun sebelumnya peserta pelatihan bisa mencapai 30-40 peserta. Hal tersebut membuktikan bahwa besarnya minat masyarakat khususnya Kabupaten Demak untuk belajar dan mendedikasikan diri untuk menjadi instruktur senam aerobik yang berlisensi resmi. Berdasarkan berbagai hal diatas, peneliti ingin mengkaji lebih dalam sebenarnya. Apakah yang mendasari masyarakat untuk mengikuti pelatihan instruktur senam level 2 yang diadakan oleh LKP Griya Dina. Masyarakat yang mengikuti pelatihan berasal dari latar belakang yang berbedabeda, tetapi masyarakat selalu semangat mengikuti senam aerobik.

\section{METODE}

Penelitian ini peneliti menggunakan jenis penelitian kualitatif deskriptif, karena peneliti ingin mendeskripsikan terkaittema yang telah dipilih yaitu motivasi peserta pelatihan instruktur senam aerobik level 2 di LKP Griya Dina Kabupaten Demak.

Lokasi yang digunakan sebagai tempat penelitian LKP Griya Dina, beralamat di Griya Bhakti Praja No A/22 Kelurahan Mangunjiwan Kecamatan Demak Kabupaten Demak Jawa Tengah. Dalam penelitian ini sumber data diperoleh melalui hasil observasi, wawancara, dan dokumentasi. Sasaran penelitian untuk pengurus atau managemen LKP Griya Dina Demak, instruktur dan peserta pelatihan. Masalah yang akan dikemukakan dalam penelitian ini adalah "Motivasi Peserta Pelatihan Instruktur Senam Aerobik Level 2 di LKP Griya Dina Kabupaten Demak Jawa Tengah”.

Sumber data diperoleh dari peserta pelatihan, instruktur dan pengurus LKP Griya Dina dengan menggunakan metode observasi, wawancara dan dokumentasi. Peserta pelatihan berjumlah 20 sebagai populasi dan jumlah sampel yang digunakan yaitu 10 peserta pelatihan, 3 instruktur senam, dan 2 pengurus LKP Griya Dina. Pengambilan sampel berjumlah 10 menggunakan purposive sampling dengan kriteria, 1. Setiap sampel memiliki kemampuan yang sama (masih pemula) yang ditentukan 
oleh pelatih dengan ketentuan, peserta paham dan bisa melakukan gerakan dasar senam aerobik. 2 . Sampel merupakan peserta aktif yang dilihat dari total keberangkatan saat mengikuti pelatihan, dilihat dari daftar hadir.

Teknik pengumpulan data pada penelitian ini menggunakan observasi, wawancara, dan dokumentasi

Observasi pada penelitian ini menggunakan observasi partisipatif, maka data yang diperoleh akan lebih lengkap, tajam, dan sampai mengetahui pada tingkat makna dari setiap perilaku yang tampak.

Wawancara atau interview dalam penelitian ini bersifat open ended artinya bahwa wawancara di mana jawabannya tidak terbatas pada satu tanggapan saja, sehingga peneliti dapat bertanya kepada informan tidak hanya tentang hakikat suatu peristiwa melainkan juga akan bertanya mengenai pendapat responden mengenai peristiwa tersebut.

Dalam teknik dokumentasi, peneliti menghimpun data-data kondisi fisik LKP, letak LKP, sarana penunjang pelatihan, dan keadaan pelatihan instruktur senam.

\section{HASIL DAN PEMBAHASAN}

Peserta pelatihan instruktur senam aerobik level 2 di LKP Griya Dina Kabupaten Demak memiliki motivasi intrinsik dan ekstrinsik dalam mengikuti pelatihan.

Hasil yang didapatkan peneliti dalam penelitian ini cukup memuaskan karena wawancara terlaksana dengan lancar meskipun harus dilaksanakan secara offline dan online serta harus tetap mematuhi protokol kesehatan karena masih dalam masa transisi. Objek dan subjek penelitian kooperatif pada saat dilakukan observasi dan wawancara, sehingga peneliti terbantukan dengan sikap objek dan subjek. Untuk peneliti lain yang ingin melakukan penelitian dengan judul serupa dan masih dalam kondisi transisi alangkah baiknya melakukan penelitian dengan tetap mematuhi protokol kesehataan yang berlaku.

Hasil penelitian ini sejalan dengan penelitian Ircham Nur Majid yang berjudul Motivasi Peserta Senam Aerobik Di Eristy Management Kota Semarang Tahun 2013 dan penelitian Metiria Zuraida, Ifwandi, dan Abdurrahman yang berjudul Motivasi Instrinsik Masyarakat Dalam Mengikuti Senam Aerobik Di Stadion Harapan Bangsa Banda Aceh Tahun 2015 yang membahas tentang motivasi peserta pelatihan senam aerobik untuk mengetahui motivasi intrinsik, motivasi ekstrinsik dan minat masyarakat 
mengikuti pelatihan senam aerobik. Penelitian yang sejalan dengan penelitian ini merupakan penelitian yang sama yaitu penilitian kualitatif deskriptif.

\section{KESIMPULAN}

Setelah melalui analisis kualitatif dan dilakukan pembahasan dari hasil penelitian tentang Motivasi Peserta Pelatihan Instruktur Senam Aerobik Level 2 Di LKP Griya Dina Kabupaten Demak Jawa Tengah, peneliti dapat memberikan kesimpulan sebagai berikut:

1. Peserta yang mengikuti pelatihan instruktur senam aerobik level 2 di LKP Griya Dina terdorong untuk mengikuti pelatihan karena adanya motivasi dari dalam diri sendiri (motivasi intrinsik) dan juga ada motivasi dari luar diri (motivasi ekstrinsik).

2. Motivasi intrinsik yang mendorong perserta untuk mengikuti pelatihan, yaitu keinginan untuk mendapatkan ilmu dari pelatihan instruktur senam aerobik, menyalurkan hobi, keinginan untuk menjadi instruktur senam aerobik serta menjaga kesehatan dan kebugaran tubuh masing-masing peserta.

3. Motivasi ekstrinsik yang mendorong peserta untuk mengikuti pelatihan, yaitu LKP atau tempat pelatihan yang sudah terakreditasi, pelatihan yang tidak dipungut biaya atau gratis, dekat dengan rumah, mendapatkan keterampilan, gerakan yang tidak monoton serta diiringi banyak irama musik, banyak peluang menjadi instruktur senam, dan mendapatkan sertifikat kompetensi keahlian.

4. Peserta pelatihan yang juga berminat menjadi instruktur senam aerobik di Kabupaten Demak karena masih banyak peluang menjadi instruktur senam aerobik di Kabupaten Demak dan mendapatkan penghasilan dari menjadi instruktur senam aerobik yang bisa digunakan unutk memenuhi kebutuhan sehari-hari.

\section{DAFTAR PUSTAKA}

A.A Anwar Prabu Mangkunegara. (2012). Manajemen Sumber Daya Manusia. Bandung: PT. Remaja Rosdakarya.

Agung, Iskandar. (2012). Panduan Penelitian Tindakan Kelas bagi Guru. Jakarta: Bestari Buana Murni.

A.M, Sardiman. (2007). Interaksi dan Motivasi Belajar Mengajar. Jakarta: Raja Grafindo Persada.

A.M, Sardiman. (2014). Interaksi dan Motivasi Belajar Mengajar. Jakarta: Rajawali Pers.

Bogdan, R. C., Biklen, S. K. (1992). Qualitative Research for Education: an Introduction to Theory and Methods, Boston: Allyn \& Bacon.

Brick, Lyne. (2001). Bugar dengan Senam Aerobik. Jakarta: Raja Grafindo Persada.

Bustaman, Amrum. 2000. Makalah yang disajikan dalam Seminar Senam. Persani Jawa Tengah. Semarang, 3-5 Maret.

Danim, Sudarwan. (2010). Perkembangan Peserta Didik. Bandung: Alfabeta

Fahrezi. F. 2002. Makalah dalam Seminar Senam General. Jakarta.

Hamalik, Oemar. (2004). Proses Belajar Mengajar. Jakarta: Bumi Aksara 
Hamzah B. Uno. (2009). Teori Motivasi dan Pengukurannya. Jakarta: Bumi Aksara.

Hamzah B. Uno. (2012). Model Pembelajaran Menciptakan Proses Belajar Mengajar yang Kreatif dan Efektif. Jakarta: PT Bumi Aksara.

Harsono. 1998. Coaching dan Aspek-aspek Psikologis dalam Coaching. Jakarta. Gunung Mulia.

Kamil, Mustofa. (2012). Model Pendidikan dan Pelatihan (Konsep dan Aplikasi). Alfabeta. Bandung

Kravitz Len. (2001). Panduan Lengkap Bugar Total. Jakarta: Rajagrafindo Persada.

Majid, Ircham Nur. (2015). Motivasi Peserta Senam Aerobik Di Eristy Management Kota Semarang Tahun 2013. Journal of Physical Education, Sport, Health and Recreations. Vol 4(2): 1590 - 1595. Semarang: Universitas Negeri Semarang.

Mangkuprawira, S., dan A.V. Hubeis, (2007). Manajemen Mutu Sumber Daya Manusia. Bogor: Penerbit Ghalia Indonesia.

Molngleong, J Lexy. (2017). Metodologi Penelitian Kualitatif. PT Remaja Rosdakarya offset. Bandung.

Rahmawati, A. \& Mulyono, S.E. (2016). Pengaruh Pelayanan Penyuluh Lapangan Terhadap Kepuasan Masyarakat Dalam Program Keluarga Berencana. Journal Of Nonformal Education. 2 (2). e-ISSN 2528-4541. 176181.

Rifa'i, A., \& Anni, C. T. (2009). Psikologi Pendidikan. Semarang: Universitas Negeri Semarang Press.

Romadhon, Sandi Akbar. (2016). Motivasi dan Minat Masyarakat Dalam Berolahraga Sepeda di Kota Semarang. Journal of Physical Education, Sport, Health and Recreation. Vol 5(1): 25 - 28. Semarang: Universitas Negeri Semarang.

Sugiyono. (2018). Metode Penelitian Kuantitatif, Kualitatif, dan R\&D. Alfabeta. Bandung.

Sumardjuno Sadoso. (2001). Latihan Olahraga Bagi Orang Dewasa. Jakarta: KONI Pusat Ilmu Keolahragaan

Suryabrata, Sumadi. (2010). Psikologi Pendidikan. Jakarta: Raja Grafindo Persada.

Sutarto, Joko. (2007). Pendidikan Nonformal (Konsep Dasar, Proses Pembelajaran, dan Pemberdayaan Masyarakat). Semarang: Unnes Press

Tilarso, Hario. 2000. Makalah yang di sajikan dalam seminar senam Yoga. Solo JawaTengah. Walgito, B. (2005). Bimbingan dan Konseling (Studi dan Karir). Jogjakarta: CV Andi Offset. 